\title{
NSMCE2 Gene
}

National Cancer Institute

\section{Source}

National Cancer Institute. NSMCE2 Gene. NCI Thesaurus. Code C131563.

This gene plays a role in protein sumoylation, DNA repair and the inhibition of apoptosis. 